\title{
Isolation of hematopoietic stem cells and the effect of CD38 expression during the early erythroid progenitor cell development process
}

\author{
IŞIL ALBENIZZ ${ }^{1}$, LEYLA TÜRKER-ŞENER ${ }^{1}$, AYCAN BAŞ $^{1}$, İBRAHIM KALELIOĞLUU $^{2}$ and RÜSTEM NURTEN ${ }^{1}$ \\ Departments of ${ }^{1}$ Biophysics, and ${ }^{2}$ Obstetrics and Gynecology, Istanbul University, \\ Istanbul Faculty of Medicine, Capa-Istanbul 34093, Turkey
}

Received June 21, 2011; Accepted October 11, 2011

DOI: $10.3892 / \mathrm{ol} .2011 .455$

\begin{abstract}
The aim of this study was to investigate changes in primitive hematopoietic cells through CD38 expression, identify the stage at which erythrocyte differentiation CD38 gains activity and the effects of serum factors on this expression by establishing a hematopoietic stem cell system in the erythroid development process. Using an immunomagnetic labeling and separation technique, $\mathrm{CD} 34^{+}$cells were selected from cord blood. The CD34+ cells were cultured in a $2 \mathrm{mM}$ L-glutamine-enriched medium containing erythropoietin (Epo), penicillin-streptomycin and stem cell factor (SCF), and were incubated in $5 \% \mathrm{CO}_{2}$ at $37^{\circ} \mathrm{C}$. In erythroid development pathways following CD38 expression, primitive/progenitor human hematopoietic cells obtained from cord blood were assessed through the erythroid development process in a serum-free medium in the presence of proper SCF and Epo. At the end of the 26-day process, using staining with a Megacult-c staining kit, it was determined that progenitor cells nucleate and differentiate into erythroid cell lines of 8-10 $\mu \mathrm{m}$. During the course of this process, we analyzed increases over time in NAD glycohydrolase activity rates using the supernatant liquid samples. Results of co-culture experiments in cell culture studies showed that the stimulating effects of CD38 expression originate from specific serum factors. CD38 expression has
\end{abstract}

Correspondence to: Dr Işil Albeniz, Istanbul University, Istanbul Faculty of Medicine, Department of Biophysics, Capa-Istanbul 34093, Turkey

E-mail: ialbeniz@istanbul.edu.tr

Abbreviations: Epo, erythropoietin; SCF, stem cell factor; HSCs, hematopoietic stem cells; HPCs, hematopoietic progenitorcells; ALDH, fluorescent aldehyde dehydrogenase; FACS, fluorescenceactivated cell sorting; APC, allophycocyanin; PE, phycoerythrin; IMDM, Iscove's modified Dulbecco's medium; BCIP, 5-bromo-4chloro-3'-indolyl phosphate p-toluidine; SDS-PAGE, sodium dodecyl sulfate polyacrylamide gel electrophoresis

Key words: hematopoietic stem cell, cord blood, CD38, NAD glycohydrolase, erythropoietin, stem cell factor been shown to occur at hematopoietic cell sources as well as at a number of differentiation levels. In the proliferation process the possible induction of CD38 through specific serum factors leads us to conclude that it may be involved in proliferation with a physiological task or that it may be involved in an event, such as an apoptotic process.

\section{Introduction}

Stem cells are unspecialized cells capable of self-renewal in a living organism through cell division, and the production of specialized cells. These cells are capable of multi-differentiation and possess the ability to become transferred tissue cells (1). Stem cells are obtained from two different sources: i) embryonic stem cells are obtained from an internal cell population of blastocysts in the earlier stages of embryonic development, and ii) postnatal stem cells are obtained from non-embryonic (organ-specific, tissue-specific or in mature stem cells) sources (2). Cells obtained from embryonic stem cells are capable of differentiating into various cell types originating from the ectoderm, mesoderm and endoderm layers, besides the placenta (3). Stem cells in mature tissues are unspecialized cells that usually generate the cell types which belong to the tissue in which they occur. These cells are also capable of regeneration, providing replenishment and repair to the tissues to which they belong. Mature stem cells differentiate into multi-cell types and this status is known as 'transdifferentiation' or 'plasticity' $(4,5)$. At present, the most commonly referenced method for identifying stem cell types is based on the use of stem cell markers. The majority of these markers, which appear on the surface of the cells and play a role in cell signaling pathways or cell-cell adhesion molecules, are known as 'clusters of differentiation' (CD), and are found specifically or commonly for the cell type (6). Hematopoietic stem cells (HSCs) are found in bone marrow and cord blood, and have in vivo engraftment potential. Peripheral blood (PB) stem-progenitor cells mobilize with growth factors. These two cell types form progressively more mature hematopoietic progenitor cells (HPCs). Due to their ability to regenerate and differentiate into all blood cells, HSCs are regarded as blood cell precursors (7). By contrast, HPCs are differentiated into various blood cells, i.e., myeloid cells (monocytes, macro- 
phages, basophils, eosinophils, erythrocytes, megakaryocytes/ platelets and some dendritic cells) and lymphocytes [T cells, B cells, natural killer (NK) cells and some dendritic cells]. The primary surface markers of these cells are CD34, CD14, CD38, CD45 and CD133. In humans, the majority of HSCs and HPCs carry CD34 phosphoglycoprotein and its mRNA. A substantial proportion of $\mathrm{CD}^{+} / \mathrm{CD} 38 / \mathrm{Lin}^{-}$cells occur within HSCs (8-10). Moreover, fluorescent aldehyde dehydrogenase (ALDH)-substrates have been used to identify and isolate human and mouse hematopoietic cells by fluorescenceactivated cell sorting (FACS) (11).

In a previous study, CD38 activity was investigated in erythrocytes obtained from different patient groups, including cancer patients and patients with systemic diseases, and was found to be higher when compared to the control group. This increased activity in cancer patient erythrocytes is significant. Additionally, in cancer cases with high carcinoembryonic antigen (CEA) values, the erythrocyte protein band corresponding to $45 \mathrm{kDa}$ molecular weight had an increased signal in the Western blot analysis, and this indicates that CD38 expression was induced in cancer (12).

Human CD38, a type II surface antigen expressed by immature hematopoietic cells, is rearranged at high levels by activated lymphocytes, such as T cells, B cells, dendritic cells and NK cells. In bone marrow, CD38 is expressed in primitive cells, and it is known that $50-80 \%$ of the mononuclear cells in cord blood are CD38-positive (13). Cell surface antigen CD38 is an enzyme with a number of functions and is also expressed in hematopoietic cells through differentiation. CD38 is a multifunctional ectoenzyme that exhibits NAD glycohydrolase, ADP ribosyl cyclase and ADP ribosyl hydrolase activities. A number of studies indicated that a high level of CD38 expression is a sign of malignancy $(14,15)$. CD38 also has receptor activity in addition to its enzymatic features. This activity is thought to play a role in cell proliferation and differentiation processes through in vivo signal transmission. By contrast, the correlation between the enzymatic features of CD38 and its receptor-like behavior remains to be determined. CD38 is considered valuable to research due to its effectiveness and physiological function. Primitive/progenitor hematopoietic cells $\left[\mathrm{CD}_{34}{ }^{+} / \mathrm{CD} 8^{-}\right]$, which are obtained from cord blood, persist in the erythroid development process until the nucleus loss stage, in addition to favorable factors [such as stem cell factor (SCF)/erythropoietin] in serum-free culture medium. Therefore, the present study aimed to investigate changes in primitive hematopoietic cells through CD38 expression, and identify the stage at which erythrocyte differentiation CD38 gains activity and the effects of serum factors on this expression in the erythroid development process. To achieve this aim, a HSC system was established.

\section{Materials and methods}

$\mathrm{CD} 4^{+}$cell isolation from cord blood. $\mathrm{CD}^{+} 4^{+}$cells were isolated by a magnetic cell-sorting system. Cord blood (10 ml) was diluted 1:1 with phosphate-buffered saline (PBS). Ficoll $(5 \mathrm{ml})$ was added to a $15 \mathrm{ml}$ tube into which diluted cord blood was gradually layered. Samples were centrifuged at $3000 \mathrm{rpm}$ for $20 \mathrm{~min}$. The buffy coat was transferred to polystyrene tubes and $1 \mathrm{ml}$ of medium [2\% fetal bovine serum (FBS) + 1 mM EDTA-containing PBS] was added to the tubes. EasySep antibody cocktail $(100 \mu \mathrm{l})$ was added following cell suspension. The mixture was then pipetted and incubated for $15 \mathrm{~min}$ at room temperature. Subsequently, $50 \mu \mathrm{l}$ of mixture containing magnetic nanoparticles was added, and the mixture was then incubated for $10 \mathrm{~min}$ at room temperature following 4-5 more pipettes. A total volume of $2500 \mathrm{ml}$ was obtained with medium and the tube that was placed inside the magnet was incubated for $5 \mathrm{~min}$. Without removing the tube from the magnet, the content of the tube was emptied following a 2-3-sec wait. The tube was removed from the magnet and washed a further four times by adding $2.5 \mathrm{ml}$ PBS. The tube content $\left(\mathrm{CD} 34^{+}\right.$cells) became isolated (16). CD34+ ${ }^{+}$cells were examined under an inverted microscope and, in terms of $\mathrm{CD} 34^{+}$cell rate, were examined by flow cytometry.

Isolation of $\mathrm{ALDH}^{+} \mathrm{CD} 38^{-}$cells with FACs after selecting CD $34^{+}$cells from cord blood. $\mathrm{CD} 4^{+}$cells from cord blood were isolated by immunomagnetic labeling. For ALDH labeling, which is a stem cell marker, $50 \mu 1$ activator was added to the reagent tube and the tube was incubated for $20 \mathrm{~min}$ at room temperature. A $1.5 \mathrm{ml}$ neutralization buffer was also added to the tube. Simultaneously, $5 \mu 1$ diethylaminobenzaldehyde (DEAB, Sigma, St. Louis, MO, USA) was added to the control tube. A $500 \mathrm{ml}$ cell sample (obtained from cord blood) was transferred to the reagent tube, and then a $500 \mu 1$ sample was transferred to the control tube. The sample was incubated for $30 \mathrm{~min}$ at $37^{\circ} \mathrm{C}$. A $1 \mathrm{ml}$ sample was collected from the reagent tube and transferred to a separate flow tube. CD34 allophycocyanin (APC) (5 $\mu \mathrm{l})$ and CD38 phycoerythrin (PE) $(5 \mu \mathrm{l})$ were added. The tubes were incubated for $20 \mathrm{~min}$ at $37^{\circ} \mathrm{C}$. Supernatants were removed following centrifugation for $5 \mathrm{~min}$ at $2000 \mathrm{rpm}$. Following the addition of $0.5 \mathrm{ml}$ measurement buffer, analysis was carried out using a FACSDiva Software 6.1.2.

Culture of phase I and II $\mathrm{ALDH}^{+} \mathrm{CD} 34^{+} \mathrm{CD} 38 \mathrm{Lin}^{-}$cells from which erythroid primitives developed. $\mathrm{ALDH}^{+} \mathrm{CD} 34^{+}$ CD38 Lin $^{-}$cells were plated at $1 \times 10^{6}$ cell $/ \mathrm{ml}$ in the $5 \mathrm{ml}$ voluminous wells. Erythropoietin (Epo) [recombinant human (rH)] $(10 \mu \mathrm{g} / \mathrm{ml}), 100 \mathrm{U} / \mathrm{ml}$ penicillin-streptomycin, $10 \mathrm{ng} / \mathrm{ml}$ IL-3 and IL-6, and $100 \mathrm{ng} / \mathrm{ml}$ SCF were added to CD34+ cells $\left(1 \times 10^{5} \mathrm{cell} / \mathrm{ml}\right)$ and $2 \mathrm{mM}$ L-glutamine-enriched Iscove's modified Dulbecco's medium (IMDM) and then incubated in $5 \% \mathrm{CO}_{2}$ at $37^{\circ} \mathrm{C}$. Cell counts were diluted in fresh medium $\left(1 \times 10^{5} / \mathrm{ml}\right)$ and maintained for 10 days. Ten days following the $\mathrm{SCF} /$ Epo incubation, the process was continued into the second phase of erythroid culture in $20 \%$ bovine serum albumin, insulin and transferrin (BIT) and $1 \mathrm{U} / \mathrm{ml}$ human Epo-containing medium. Transforming growth factor (TGF- $\beta 1)(5 \mathrm{ng} / \mathrm{ml})$ was added to the cultures on days 0,5 and 10 of phase II. Cells, which had been followed on different days $(0,4,8,12$ and 16$)$ of the maturation (normoblast/erythroblast) by flow cytometry, were evaluated by staining with a Megacult-c staining kit.

Assay for NAD glycohydrolase activity of hematopoietic progenitor cells. The NAD glycohydrolase enzyme activity of $\mathrm{ALDH}^{+} \mathrm{CD} 34^{+} \mathrm{CD} 38^{-}$cells cultured with $\mathrm{SCF}$ was examined 
by supernatant samples obtained on different days $(0,4,8,12$ and 16) (cell counts were maintained as a constant).

$\mathrm{NAD}^{+}$glycohydrolase activity of $\mathrm{ALDH}^{+} \mathrm{CD} 34^{+} \mathrm{CD} 38$ cells cultured with $\mathrm{SCF}$ was determined by the separation of [carbonyl $-{ }^{14} \mathrm{C}$ ] nicotinamide released from [carbonyl- ${ }^{14} \mathrm{C}$ ] $\mathrm{NAD}^{+}$in BioRad AG1X4 anion exchange resin (BioRad, Hercules, CA, USA) (17). Reaction mixtures (20 $\mu \mathrm{l}, \mathrm{pH} 9.0)$ containing $12 \mu \mathrm{l}$ serum, $10 \mathrm{mM} \mathrm{NaCl}, 500 \mu \mathrm{M} \mathrm{ZnCl}_{2}, 50 \mu \mathrm{M}$ $\mathrm{CaCl}_{2}, 20 \mathrm{mM}$ Tris- $\mathrm{HCl}$ and $5 \mu \mathrm{M}$ [carbonyl $-{ }^{14} \mathrm{C}$ ] $\mathrm{NAD}^{+}$were incubated for $30 \mathrm{~min}$ at $37^{\circ} \mathrm{C}(12)$. Reactions were stopped with $1 \mathrm{ml} 0.1 \%$ sodium dodecyl sulfate (SDS). The samples were then applied to a BioRad AG1X4 column and [carbonyl- ${ }^{14} \mathrm{C}$ ] nicotinamide was eluted with $\mathrm{H}_{2} \mathrm{O}$, whereas unhydrolised [carbonyl $-{ }^{14} \mathrm{C}$ ] NAD was retained on the column and then eluted with $0.5 \mathrm{M} \mathrm{NaCl}$. The radioactivity was determined by counting aliquots from the eluate in a liquid scintillation counter (Packard Tri-Carb 1000 TK; Meriden, CT, USA), with a counting efficiency of $90 \%$ for ${ }^{14} \mathrm{C}$.

SDS-PAGE and Western blotting. SDS-PAGE and Western blotting using CD38-specific goat polyclonal IgG (M-19) were performed as previously described $(18,19)$. Bovine serum albumin (BSA) (66 kDa), ovalbumin (45 kDa) and carbonic anhydrase $(29 \mathrm{kDa})$ were used as standards.

SDS-PAGE analyses of stem cell culture supernatant liquids were made by using the Laemmli method (18). Stem cell culture supernatant liquids were solubilized in $1 \mathrm{M}$ Tris- $\mathrm{HCl}, \mathrm{pH}$ 6.8, 2\% glycerin, $10 \%$ SDS, 5\% 2-mercaptoethanol and $0.1 \%$ bromphenol blue, and subjected to SDS-PAGE. The separated proteins were then transferred electrophoretically onto nitrocellulose membranes (Schleicher \& Schuell BioScience, Dassel, Germany). The blots were blocked by $1 \mathrm{~h}$ incubation with $0.5 \%$ BSA in TBST (10 mM Tris- $\mathrm{HCl}$, $\mathrm{pH} 8.0,150 \mathrm{mM} \mathrm{NaCl}$ and $0.05 \%$ Tween-20) followed by successive $1 \mathrm{~h}$ incubations with CD38-specific goat polyclonal IgG (M-19). Detection of immunocomplexes was achieved using alkaline phophatase-conjugated bovine antigoat antibody (Sigma) [1:1000 in TBST and nitrotetrazolium blue chloride/5 bromo-4 chloro-3'-indolyl phosphate (BCIP/ NBP)] tablets as the substrate (12).

Statistical analysis. Each experiment was repeated at least three times. Results were expressed as the mean value \pm standard deviation (SD). A paired t-test was used for statistical analyses of data. $\mathrm{P}<0.05$ was considered to be statistically significant and tests were two-tailed. Statistical analyses were performed using the statistical package SPSS 10.1 (SPSS, Chicago, IL, USA).

\section{Results}

Isolation of hematopoietic progenitor cells. $\mathrm{CD}_{3} 4^{+}$cells from cord blood were selected by immunomagnetic labeling and sorted with FACS. With the P1 gate, cells showing lymphocyte morphology were gated; a total of 10.000 cell were gated. From the selected cells, a CD $34^{+} \mathrm{CD} 38^{-}$cell group was gated, (P5) $29.6 \%$, and an ALDH rate was obtained from this cell group. From the $\mathrm{ALDH}^{+}$, (P6) 7.4\%, and $\mathrm{ALDH}^{-}$, (P7) $90.2 \%$, populations, the $\mathrm{CD}^{+} 4^{+} \mathrm{CD} 38-\mathrm{ALDH}^{+}$, (P8) $6.8 \%$, section was sorted (Fig. 1).
Generation of erythroid progenitors from primitive hematopoietic cells in liquid culture (phase I). Essential cytokines and factors [Epo (1 $\mu \mathrm{l} / \mathrm{ml}), \mathrm{SCF}(100 \mathrm{ng} / \mathrm{ml}), \mathrm{IL}-3(10 \mathrm{ng} / \mathrm{ml})$, and IL-6 (10 ng/ml)] were added to 20\% BIT 9500, $100 \mathrm{U} / \mathrm{ml}$ penicillin-streptomycin and 15\% FBS-containing medium, and collected hematopoietic progenitor $\left(\mathrm{ALDH}^{+} \mathrm{CD} 34^{+} \mathrm{CD} 38^{-}\right)$ cells were cultured in $2 \mathrm{mM}$ L-glutamin-enriched IMDM. Cell counts were maintained $<1 \times 10^{6} / \mathrm{ml}$ by repeated cell dilutions in fresh medium.

Terminal erythroid differentiation in liquid culture (phase II). Following 10 days of SCF/Epo stimulation, the washed cells were transferred into the second phase of the erythroid culture in $20 \%$ BIT $\left(2 \times 10^{5} / \mathrm{ml}\right)$ (phase II, 14 days), $10^{-5} \mathrm{M}$ $\beta$-mercaptoethanol ( $\beta$-ME), $10^{-5} \mathrm{M}$ dexamethasone and $1 \mathrm{U} / \mathrm{ml}$ $\mathrm{rH}$ Epo-containing IMDM. TGF- $\beta 1(5 \mathrm{ng} / \mathrm{ml})$ was added on days 0,5 and 10 of phase II. Cells which had been followed on different days $(0,4,8,12$ and 16) of maturation (normoblast/ erythroblast) were assessed by staining with a Megacult-c staining kit (Fig. 2).

The cell count resulted in significant cell proliferation in Epol $S C F$-stimulated cultures. This proliferation was correlated to erythroid cell generation in SCF/Epo-stimulated cultures. In the second differentiation phase on different days $(0,4,8,12$ and 16), flow cytometric analyses of cells were carried out. Results showed that CD38 activities of cells increased over time, whereas CD34 percentages decreased.

NAD glycohydrolase activity of hematopoietic progenitor cells. $\mathrm{CD}^{+} 4^{+} \mathrm{CD} 38^{-} \mathrm{ALDH}^{+}$cells cultured with SCF were transferred into Epo and SCF-containing medium for phase I, which is the erythroid line differentiation stage. Ten days later, the cells were transferred into the second phase medium, which contained transforming growth factor $\beta 1$, mercaptoethanol and dexamethasone. A significant increase was observed in the activity rates of NAD glycohydrolase obtained from the supernatant samples on different days $(0,4$, 8, 12 and 16) of the differentiation phase (Fig. 3). At the end of the 16th day, activity rates were approximately 10 times more compared with days 0 and 4 . The paired t-test was used for statistical analyses of data. $\mathrm{P}<0.05$ was considered to be statistically signficant and tests were two-tailed.

Second differentiation phase Western blot analysis. On different days $(0,4,8,12$ and 16) during the second differentiation phase, Western blotting analyses of supernatants cultured with SCF were performed following SDS-PAGE. From the eighth day of differentiation, an increase over time was determined on a signal correlated to a 45-kDa molecular weight protein, which reacts with anti-CD38 (Fig. 4).

NAD glycohydrolase activity of HSCs in the presence of serum factors. We have analyzed the effects of serum factors on co-culture experiments and CD38 expression in cell culture studies by using a NAD glycohydrolase activity test. The following media were added in the experiments conducted on $5 \times 10^{5} / \mathrm{ml} \mathrm{CD} 34^{+} \mathrm{CD} 38{ }^{-} \mathrm{ALDH}^{+}$HSCs: only Epo was added to the first well; control serum to the second and third wells; patient serum with a low CEA value to the fourth well; and 

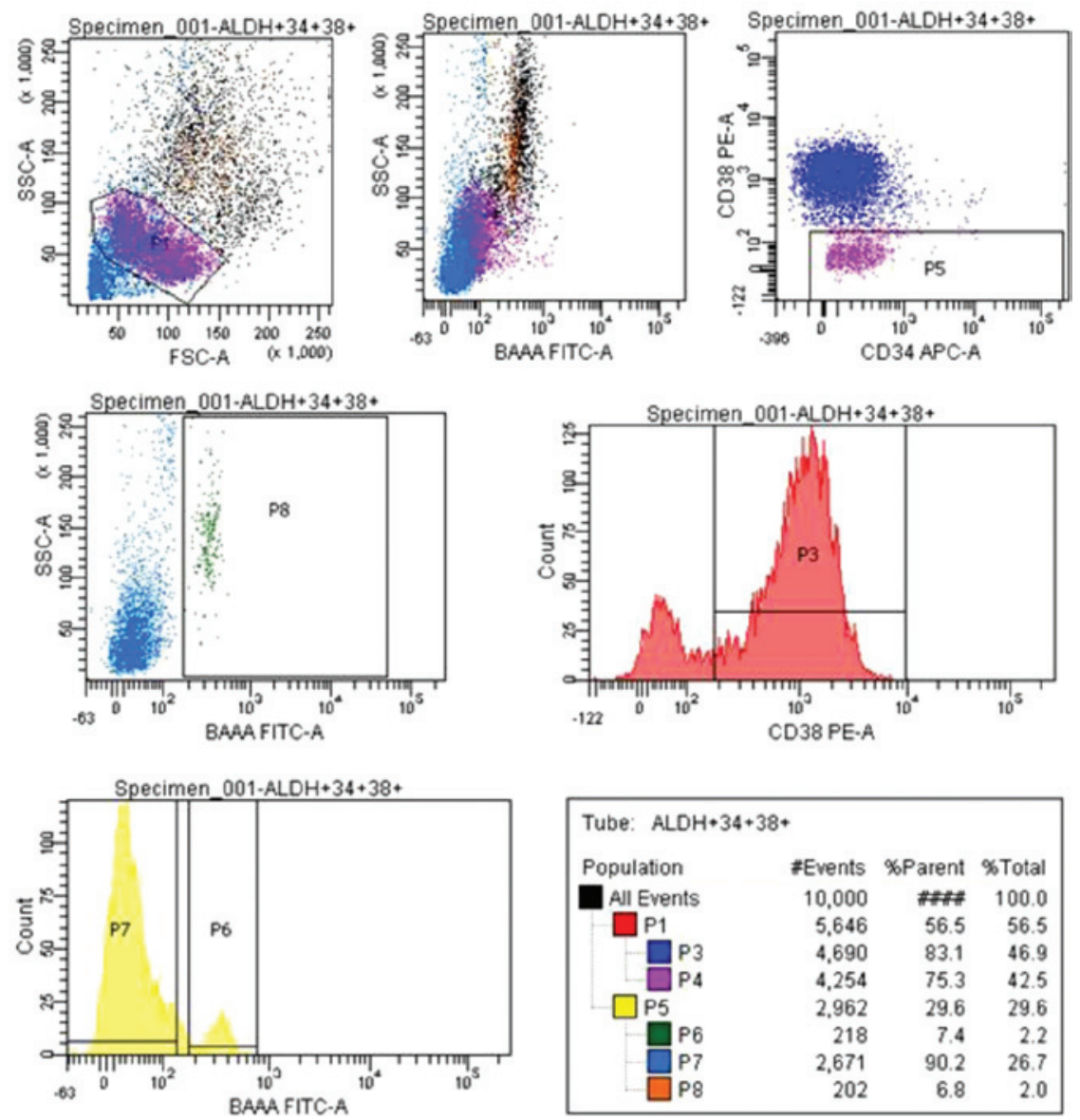

Figure 1. Isolation of hematopoietic progenitor cells. Following isolation of $\mathrm{CD} 34^{+}$cells from cord blood, cells were treated with CD38-PE labeled antibody for CD38 antigen. Through labeled antibody CD38-ALDH ${ }^{+}$cells were sorted by FACS. At the number 1 dot plot, a lymphocyte gate was obtained from CD34 cells. Subsequently, gated cells were analyzed at CD34 (P4) and CD38 (P3) parameters. By gating the CD34 ${ }^{+} \mathrm{CD} 38^{-}$cell group (P5) from CD34 $/ \mathrm{CD}^{-} 38^{-}$ parameter, $\mathrm{ALDH}$ rates were analyzed. From the $\mathrm{ALDH}^{+}(\mathrm{P} 6)$ and $\mathrm{ALDH}^{-}(\mathrm{P} 7)$ populations, the $\mathrm{ALDH}^{+}(\mathrm{P} 8)$ section was isolated by sorting.

A

\section{B}

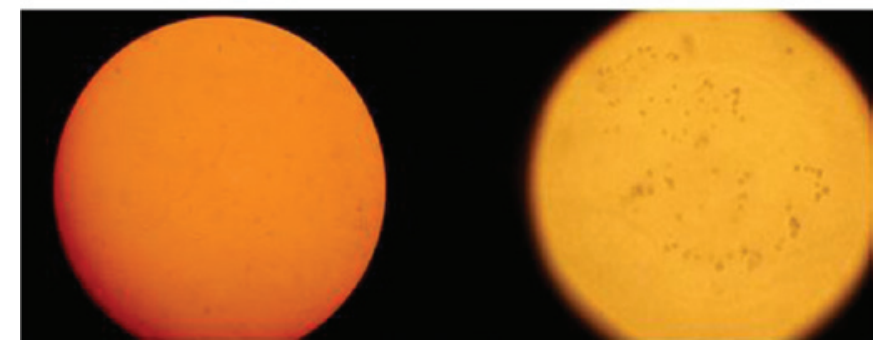

Figure 2. Cells which were transferred into the second phase culture medium on different days $(1,4,8,12$ and 16) and stained using a Megacult c-staining kit. Light microscope images of cells stained with the Megacult c-staining kit on (A) the first and (B) sixteenth days.

patient serum with a high CEA value to the fifth well. Seven days later, the NAD glycohydrolase activity of supernatants was analyzed. A significant increase in NAD glycohydrolase activity, in other words CD38 expression, compared to other wells was determined in the well to which cancerous patient serum was added (Fig. 5). The paired t-test was used for statistical analyses of data. $\mathrm{P}<0.05$ was considered to be statistically significant and the tests were two-tailed.

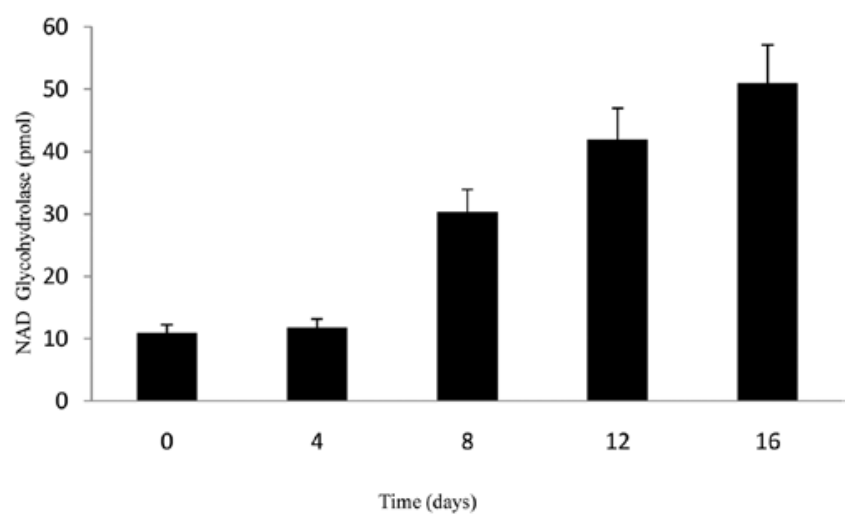

Figure 3. Time-dependent NAD glycohydrolase activity changes of progenitor cells were transferred into the second phase. A significant increase was observed in the NAD glychohydrolase activity rates obtained from the supernatant samples on different days $(0,4,8,12$ and 16$)$ of the differentiation phase. A paired t-test was used for statistical analyses of data. $\mathrm{P}<0.05$ was considered to be statistically significant and tests were two-tailed.

\section{Discussion}

In this study, $\mathrm{CD} 34^{+}$cells from cord blood were labeled immunomagnetically and sorted with FACS. The collected hematopoietic progenitor cells were transferred into culture 


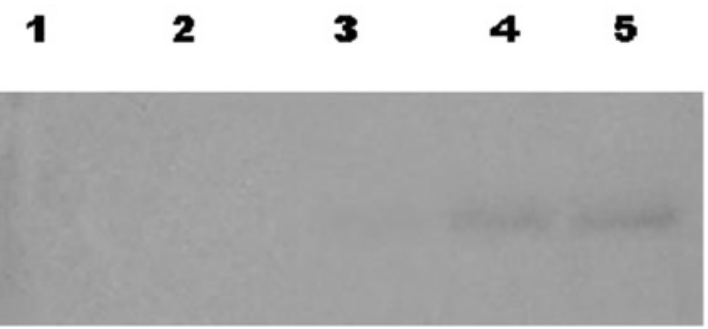

Figure 4. Western blotting analyses of differentiation of the second phase on different days $(0,4,8,12$ and 16$)$ following SDS-PAGE. Lane 1, day 0 ; lane 2, day 4; lane 3, day 8; lane 4, day 12 ; and lane 5, day 16 supernatant samples.

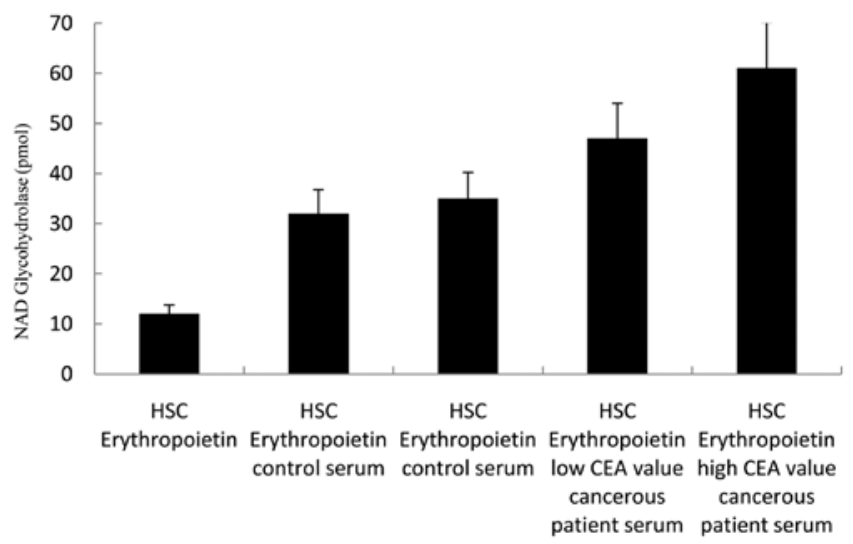

Figure 5. NAD glycohydrolase activity of hematopoietic stem cells in the presence of serum factors. Media added in the experiments conducted on $5 \times 10^{5} \mathrm{CD}_{3} 4^{+} \mathrm{CD} 38 \mathrm{ALDH}^{+}$HSCs were: only Epo was added to the first well; control serum to the second and third wells; patient serum with high CEA (carcinoembryonic antigen) value to the fourth; and patient serum with low CEA value to the fifth well. After seven days, NAD glycohydrolase activity of supernatants was analyzed. A paired t-test was used for statistical analyses of data. $\mathrm{P}<0.05$ was considered to be statistically significant and tests were two-tailed.

medium and erythroid progenitors were developed in both phases I and II.

In their study, Storms et al have shown that various primitive progenitor cells that are capable of generating into a number of lines are more substantial than $\mathrm{ALDH}^{+} \mathrm{CD} 34^{+}$ cell lines and myeloid progenitors (20). We observed that a number of $\mathrm{CD}_{3} 4^{+}$cells were $\mathrm{ALDH}^{+}$as a result of fluorescent microscopic and the flow cytometry of ALDH-fluorescein isothiocyanate (ALDH-FITCH)-labeled CD34+ cells isolated from cord blood.

The cell counts resulted in significant cell proliferation in Epo/SCF-stimulated cultures. This proliferation in SCF/ Epo-stimulated cultures is significantly correlated to erythroid cell generation. $\mathrm{CD} 34^{+} \mathrm{CD} 38^{-}$cells are primitive subpopulations of progenitor cells.

According to Hao et al, $\mathrm{CD} 34^{+} \mathrm{CD} 38^{-}$cells in cord blood show the same immunophenotype as mature bone marrow cells isolated from cord blood that proliferate seven times more rapidly in the presence of SCF and IL-6 compared to bone marrow (21).

$\mathrm{ALDH}^{+} / \mathrm{CD} 34^{+} / \mathrm{CD} 38^{-}$cells were collected during progenitor cell sorting from cord blood with FACS. Prior to the selection process they were observed using fluorescent microscope images, from which cord blood leukocyte fractions were analyzed, and cells with overall consumed antibodies were present in this fraction.

Neildez-Nguyen et al identified an essential medium required for HSCs originating in the cord blood in order to differentiate into red blood cells (22).

By performing a more extended study in vitro, stem cells were placed into a two-phased culture study. Cells that were maintained in the first phase for 10 days were transferred into the second phase, which is the differentiation period, and maintained in this medium for 16 days. Through the erythropoietic development process, hematopoietic cells were observed until the erythroblast/normoblast stage. At the end of a 26-day process, by staining cells with a Megacult c-staining kit, it was established that progenitor cells nucleate and differentiate into 8-10 $\mu \mathrm{m}$-sized erythroid cell lines $(22,23)$.

CD38 is an ectoenzyme that has NAD glycohydrolase, ADP ribosyl cyclase and ADP ribosyl hydrolase activities. $\mathrm{NAD}^{+}$glycohydrolase is usually found partially in cell and partially in nucleus (24). CD38 has also been determined in erythrocytes, the liver, pancreas, brain, muscle cells, plasma cells, monocyte/macrophages and HSCs (24-25). CD38 has receptor activity in addition to enzymatic functions. This activity is thought to play a role in cell proliferation and differentiation processes through in vivo signal transmission. However, the correlation between the enzymatic characteristics of CD38 and its receptor-like behavior remains unknown.

CD38 is a significant system that is worth investigating in terms of its effect on systems and its physiological function. In the study by Albeniz et al (12), CD38 activity was investigated in erythrocytes obtained from different patient groups, and this activity in the erythrocytes of patients with cancer and systemic diseases was found to be higher compared with the control group. This increased activity in the cancer patient erythrocytes was notably significant. Furthermore, in cancer cases with a high CEA value, an erythrocyte protein band corresponding to a $45-\mathrm{kDa}$ molecular weight had an increased signal in the Western blot analysis, and this indicates that CD38 expression was induced in cancer (12).

In this study, as an indication of the stage at which CD38 erythroid expression begins, supernatants obtained from stem cells differentiating into an erythroid cell line increase NAD glycohydrolase activity rates. This activity increase was also observed in results obtained from the Western blot analysis carried out following SDS-PAGE at a $45-\mathrm{kDa}$ anti-CD38 reactive band as of day 8 .

Previous studies have shown that when significant changes in NAD/ADP-ribose metabolism occur, CD38 expression increases and significant associated enzymatic activities occur in neoplastic development $(15,26)$.

Finally, the effects of serum factors on CD38 expression were assessed in the experiments carried out on $\mathrm{CD}^{+} 4^{+} / \mathrm{ALDH}^{+} / \mathrm{CD} 38^{-} \mathrm{HSCs}$. Serum samples from healthy individuals, and from cancer patients with high CEA rates $(>100 \mathrm{ng} / \mathrm{ml})$ and low CEA rates $(<100 \mathrm{ng} / \mathrm{ml})$ were suspended in vitro in medium and seven days later NAD glychohydrolase activity was assessed in the supernatant samples. Findings of the present study show an increase in NAD glycohydrolase 
activity. These indications suggest that the stimulative effect on CD38 expression may originate from certain serum factors.

CD38 becomes a prominent system for research in terms of its effect on form and physiological function. Cord blood cell cultures were thought to be a new model system in the study of CD38 expression in the erythrocyte development pathway. Primitive/progenitor hematopoietic cells obtained from cord blood [CD34 $\left./ \mathrm{CD} 38^{-}\right]$perpetuate the erythroid development process in a serum-free culture medium with the addition of favorable factors (such as SCF/Epo) until the nucleus loss stage is achieved (6). CD38 induction occurs at a number of differentiation stages of hematopoietic cells. The stimulative effect on CD38 expression suggests certain serum factors responsible for the induction of CD38. In the proliferation process, the possible induction of CD38 through certain serum factors suggests that it may be an event in the proliferation and apoptotic processes. CD38 cells were protected from apoptosis through their receptor functions and cooperation with a number of signaling pathways. Thus, CD38 cells exhibit a longer survival rate, an increased proliferation potential and contribute to malignancy. This is a study in which the effects of HSCs on CD38 expression were analyzed in the erythroid development process, and it is a pre-study that constitutes the first step for characterization studies of the physiological function of CD38 for stem cell applications.

\section{References}

1. Verfaillie CM, Pera MF and Lansdorp PM: Stem cells: hype and reality. Hematology 1: 369-391, 2002.

2. Mitchell KE, Weiss ML, Mitchell BM and Martin P: Matrix cells from Wharton's jelly from neurons and glia. Stem cells 21: 50-60, 2003.

3. Czyz J, Wiese C, Rolletschek A, Blyszczuk P, Cross M and Wobus AM: Potential of embryonic and adult stem cells in vitro. Biol Chem 384: 1391-1409, 2003.

4. Malik P, Fisher TC, Barsky LW, Zeng L, Izadi P, Hiti AL, Weinberg KI, Coates TD, Meiselman HJ and Kohn DB: An in vitro model of human red blood cell production from hematopoietic progenitor cells. Blood 91: 2664-2671, 1998.

5. Bickenbach JR and Stem MM: Plasticity of epidermal stem cell: survival in various environments. Stem Cell Rev 1: 71-77, 2005.

6. Sato N, Sanjuan IM, Heke M, Naef F and Brivaniou AH: Molecular signature of human embryonic stem cells and its comporation with the mouse. Dev Biol 260: 404-413, 2003.

7. Audet J, Miller CL, Rose-John S, Piret JM, and Eaves CJ: Distinct role of gp130 activation in promoting self-renewal divisions by mitogenically stimulated murine hematopoietic stem cells. Proc Natl Acad Sci USA 98: 1757-1762, 2001.

8. Forsberg EC, Prohaska SS, Katzman S, Heffner GC, Stuart JM and Weissman IL: Differential expression of novel potential regulators in hematopoietic stem cells. PLoS Genet 1: 281-294, 2005.

9. Venezia TA, Merchant AA, Ramos CA, Whitehouse NL, Young AS, Shaw CA and Goodell MA: Molecular signatures of proliferation and quiescence in hematopoietic stem cells. PLoS Biol 2: 1640-1651, 2004.
10. Steidl U, Kronenwett R, Rohr UP, Fenk R, Kliszewski S, Maercker C, Neubert P, Aivado M, Koch J, Modlich O, et al: Gene expression profiling identifies significant differences between the molecular phenotypes of bone marrow-derived and circulating human CD34+ hematopoietic stem cells. Blood 99: 2037-44, 2002

11. Wognum WA, Eaves CA and Thomas ET: Identification and isolation of hematopoietic stem cells. Arch Med Res 34: 461-475, 2003.

12. Albeniz I, Demir Ö, Türker-Şener L, Yalçıntepe L, Nurten R and Bermek E: Erythrocyte CD38 as a prognostic marker in cancer. Hematology 12: 409-414, 2007.

13. Funaro A, Reinis M, Trubiani O, Santi S, Di Primio R and Malavasi F: CD38 functions are regulated through an internalization step. J Immunol 160: 2238-2247, 1998.

14. Mainou-Fowler T, Dignum HM, Proctor SJ and Summerfield GP: The prognostic value of CD38 expression and its quantification in B cell chronic lymphocytic leukemia (B-CLL). Leuk Lymphoma 45: 455-462, 2004.

15. Matrai Z: CD38 as a prognostic marker in CLL. Hematology 10: 39-46, 2005.

16. Akel S, Petrow-Sadowski C, Laughlin MJ and Ruscett FW: Neutralization of autocrine transforming growth factor- $\beta$ in human cord blood $\mathrm{CD} 4^{+} \mathrm{CD} 38 \mathrm{Lin}^{-}$cell promotes stem cell factor-mediated erythropoetin-independent early erythroid progenitor development and reduces terminal differentiation. Stem Cells 21: 557-567, 2003.

17. Kim H, Jacobson EL and Jacobson MK: Synthesis and degradation of cyclic ADP-ribose by NAD glycohydrolase. Science 261: 1330-1333, 1993.

18. Laemmli UK: Cleavage of structural proteins during the assembly of the head of bacteriophage T4. Nature 227: 680-685, 1970.

19. Gershoni JM and Palade GE: Protein blotting: Principles and applications. Anal Biochem 131: 1-15, 1983.

20. Storms RW, Green PD, Safford KM, Niedzwiecki D, Cogle CR, Colvin OM, Chao NJ, Rice HE and Smith CA: Distinct hematopoietic progenitor compartments are delineated by the expression of aldehyde dehydrogenase and CD34. Blood 106: 95-102, 2005.

21. Hao QL, Smogorzewska EM, Barsky LW and Crooks GM: In vitro identification of single CD34+CD38- cells with both lymphoid and myeloid potential. Blood 91: 4145-4151, 1998.

22. Neildez-Nguyen TM, Wajcman H, Marden MC, Bensidhoum M, Moncollin V, Giarratana MC, Kobari L, Thierry D and Douay L: Human erythroid cells produced ex vivo at large scale differentiate into red blood cells in vivo. Nature Biotechnology 20: 467-472, 2002

23. Dorn I, Lazar-Karsten P, Boie S, Ribbat J, Hartwig D, Driller B, Kirchner $\mathrm{H}$ and Schlenke P: In vitro proliferation and differentiation of human $\mathrm{CD}_{3} 4^{+}$cells from peripheral blood into mature red blood cells with two different cell culture systems. Transplant Cell Eng 48: 1122-1132, 2008.

24. Jacobson MK, Laurean DC, Strohm MS and Jacobson EL: NAD glycohydrolase and the metabolism of cyclic ADP-ribose. Biochimie 77: 341-344, 1995.

25. Zocchi E, Franco L, Guida L, Benatti U, Bargellesi A Malavasi F, Lee $\mathrm{HC}$ and De Flora A: A single protein immunologically identified as CD38 displays $\mathrm{NAD}^{+}$glycohydrolase, ADPribosylcyclase and ADP-ribose hydrolase activities at the outer surface of erythrocytes. Biochem Biophys Res Commun 196: 1459-1465, 1993.

26. Albeniz I, Demir Ö, Nurten R and Bermek E: NAD glycohydrolase activities and ADP-ribose uptake in erythrocytes from normal subject and cancer patients. Bioscience Rep 24: 41-53, 2004. 